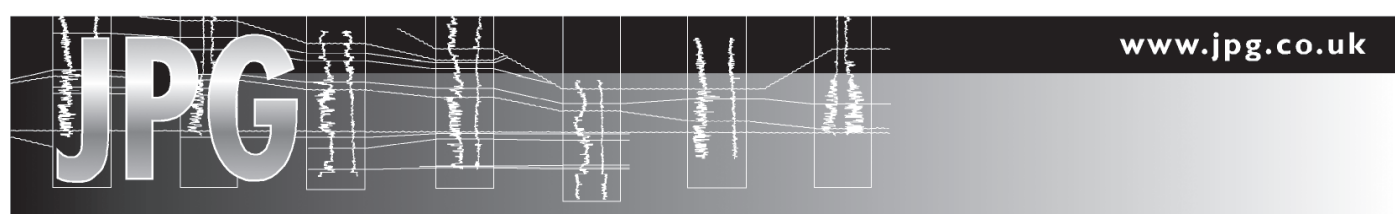

Journal of Petroleum Geology, Vol. 35(4), October 2012, pp 377 - 388

\title{
DISTRIBUTION AND ISOMERIZATION OF TERPANES IN PYROLYZATES OF LIGNITE AT HIGH PRESSURES AND TEMPERATURES
}

\author{
Chuanyuan Wang ${ }^{\mathrm{a}, \mathrm{c}}$, Jianguo $\mathrm{Du}^{\mathrm{b} *}$, Wanchun Wang \\ Baoxiang $W_{u^{c}}$ and Xiaocheng Zhou
}

Experimental pyrolysis of Eocene lignite in the presence of water was conducted in a closed system for a heating duration of $120 \mathrm{~min}$ at temperatures of $400,500,600$ and $700{ }^{\circ} \mathrm{C}$ and pressures of I to $3 \mathrm{GPa}$ (equivalent to burial depths of about 30 to $100 \mathrm{~km}$ ). The distribution of terpanes in the resulting pyrolysates was analyzed in order to investigate the effects of pressure and temperature on maturation of organic matter for this heating time at mantle depths. The results indicate that terpanes show more mature characteristics with increasing temperature at a given pressure. However, high pressures significantly retarded the thermal evolution of organic matter. Also, high pressures had a non-linear effect on maturation, resulting in anomalous variations of maturity parameters and ratios (tricyclics / hopanes, Ts/Tm, $C_{31} 22 S$ / $(22 S+22 R$ ), and $\beta \alpha$-moretane / $\alpha \beta$-hopanes). In addition, the isomerization of hopanes at the C-22 position did not reach typical end-point values, even at $700^{\circ} \mathrm{C}$. These results are a preliminary step towards a better understanding of organic matter maturation and oil and gas exploration in high temperature and pressure regimes.

\section{INTRODUCTION}

Abnormal fluid pressures are common in sedimentary basins (e.g. Person and Garven, 1992; McTavish, 1998; Osborne and Swarbrick, 1997; Carr, 1999; Zou and Peng, 2001; Li et al., 2004; Hao et al., 1995; 2004), and more than 180 overpressured basins are known worldwide (Hao et al., 2004). Disequilibrium compaction and fluid volume expansion during gas generation are considered to be the major causes of overpressure generation. Hunt (1990) proposed that

\footnotetext{
a Yantai Institute of Coastal Zone Research, Chinese Academy of Sciences, Yantai 264003, China.

b Institute of Earthquake Science, China Earthquake Administration, Beijing 100036, China.

c Lanzhou Research Center of Oil \& Gas Resources, Institute of Geology and Geophysics, Chinese Academy of Sciences, Lanzhou 730000, China.

email for correspondence: jianguodu@hotmail.com
}

much of the world's oil and gas has been generated from source rocks with overpressured fluid compartments, and that fluid thermal expansion and hydrocarbon generation can result in overpressuring within sealed compartments within a basin.

The role of overpressures in organic matter maturation has been investigated because of its importance in oil and gas resource assessments, and its influence on the preservation of petroleum in deep reservoirs. However, experimental studies of the effects of overpressure on organic matter evolution have given conflicting results. Thus, some studies have shown that increasing pressures have no detectable effects on organic-matter maturation (Monthioux et al., 1986). Increasing pressures have also been found to increase hydrocarbon thermal

Key words: High temperature and pressure, lignite, terpane, organic matter maturation, isomerization, experimental pyrolysis, mantle rocks, retardation. 


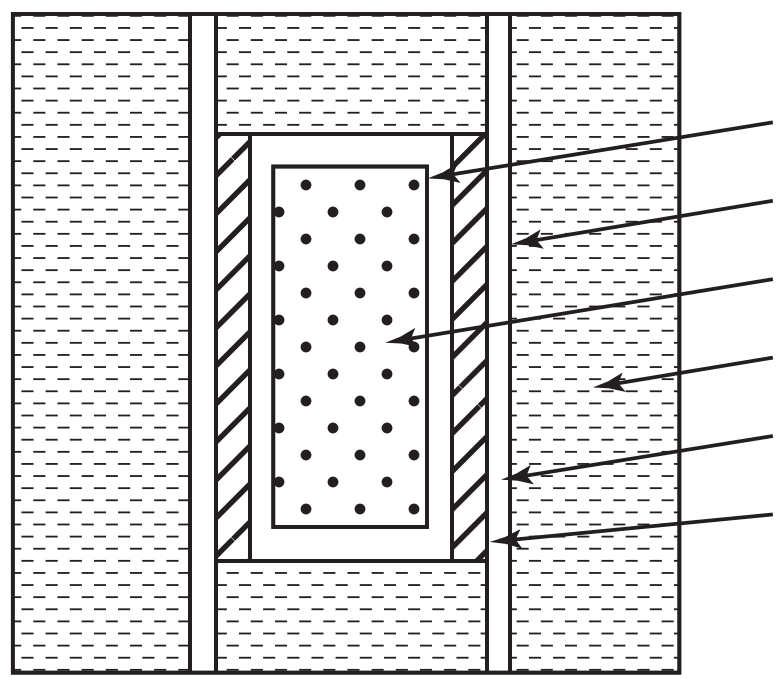

(1)
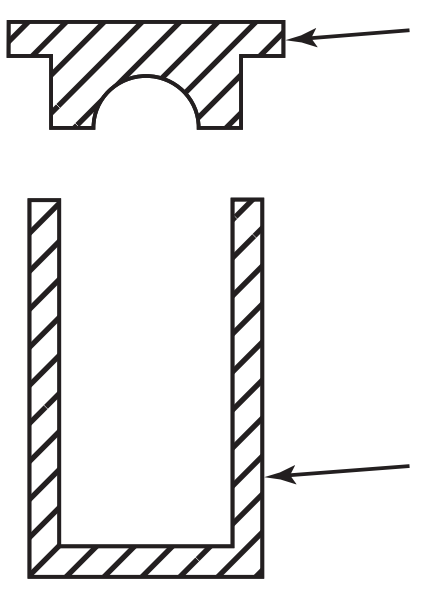

Fig. I. Cross section of the pressure cell assembly. (I) copper capsule; (2) sample; (3) copper cylinder; (4) pyrophylite as the pressure-transmitting medium; (5) heating foil; (6) alumina insulating tube; (7) the cover of the copper cylinder.

degradation (Braun and Burham, 1990) and to retard the maturation of organic matter and hydrocarbon generation significantly (Price and Wenger, 1992; Carr, 1999; Le Bayon et al., 2011).

Hydrocarbons have been found in mantle rocks and meteorites as well as within sedimentary basins (Deines, 2002). The organic matter in mantle rocks has been subjected to high-pressure and temperature (HPT) conditions. However, the origins and stability of organic matter during high-pressure metamorphism are poorly understood (Sephton et al., 2002).

Terpanes are found widely in rocks and soils as well as petroleum and coals, and are more stable than $n$-alkanes. This paper reports on the distribution of terpanes produced by pyrolysis of lignite in a closed hydrous system for a unique heating time of $120 \mathrm{~min}$ at temperatures of 400, 500, 600 and $700{ }^{\circ} \mathrm{C}$ and pressures of 1 to $3 \mathrm{GPa}$.

\section{SAMPLES AND EXPERIMENTAL METHODS}

\section{Samples}

Lignite samples were collected from Eocene coalbearing strata in mines in the Nanning Basin, Guangxi Zhuang Autonomous Region, SW China. The total organic carbon (TOC) of the samples averaged $26.32 \%$. Microscope studies showed that lignite typically contains about $77 \%$ huminite, $1.6 \%$ inertinite, $18 \%$ clay minerals, $2 \%$ quartz and $1.4 \%$ other materials. The lignite samples were dried at room temperature and pulverized with an agate mortar for HPT experimentation.

Initial lignite samples were characterized by $n \mathrm{C}_{12}$ to $n \mathrm{C}_{35} n$-alkanes with a bimodal distribution (main peaks: $n-\mathrm{C}_{16}$ and $n-\mathrm{C}_{27}$ ), odd-even predominance $(\mathrm{OEP})=2.89$, pristane/phytane ratio $(\mathrm{Pr} / \mathrm{Ph})=1.39$, vitrinite reflectance values, $\mathrm{R}_{\mathrm{o}}\left(\mathrm{VR}_{\mathrm{r}}\right)$ of $0.45 \%$ to $0.48 \%$ with high relative abundance of $\mathrm{C}_{29}$ steranes, indicating that the lignite was deposited in an oxidising environment and was mainly derived from terrigenous higher plant material.

\section{Experimental methods}

HPT pyrolysis was conducted with a YT-3000t press, a hexahedron anvil press (Fig. 1), in a closed system at temperatures of 400, 500, 600 and $700{ }^{\circ} \mathrm{C}$ and pressures of 1 and $3 \mathrm{GPa}$ for $120 \mathrm{~min}$. About $80 \%$ of lignite powder and $20 \%$ (vol.) of distilled water were placed in a copper capsule (about $0.35 \mathrm{ml}$ ), which was mechanically compressed to expel free air and to minimize the effects of oxygen and nitrogen. The capsules were sealed by a low-temperature weld after filling in order to prevent the samples from premature heating. The pressure cell was loaded into the chamber of the press and pressure was applied to the cell by six anvils through pyrophylite as a pressuretransmitting medium. The detailed structure of the press and the methods of temperature and pressure measurements were described by $\mathrm{Du}$ et al. (2003). The calibrated apparatus had an accuracy of \pm 0.01 GPa. The temperature of the pressure cell was recorded electronically and calibrated with a Pt-Pt10Rh thermocouple. The temperature reading had an error of $\pm 5^{\circ} \mathrm{C}$. Pressure was loaded from outside the sealed vessel and was automatically adjusted as it was developed by fluids inside the vessel during heating, simulating HPT conditions in the upper mantle.

Extraction of the pyrolyzates, fractionation and analysis with a gas chromatograph - mass spectrometer (GC-MS) apparatus were performed at the Lanzhou Institute of Geology, Chinese Academy of Sciences. The pyrolysates were ground to 100 
Table I. Variation in yields of chloroform bitumen "A" and other fractions in the sample (lignite) and the experimental pyrolysates, together with the characteristcs of $n$-alkanes and aromatics at different temperatures and pressures.

\begin{tabular}{|c|c|c|c|c|c|c|c|}
\hline \multirow{3}{*}{$\begin{array}{c}\text { P } \\
\text { (GPa) }\end{array}$} & \multirow{3}{*}{$\mathrm{T}\left({ }^{\circ} \mathrm{C}\right)$} & \multirow{2}{*}{\multicolumn{3}{|c|}{$\frac{\text { Fractions }}{(\mathrm{mg} / \mathrm{g} \text { TOC })}$}} & \multirow{2}{*}{\multicolumn{2}{|c|}{ Sat. }} & \multirow{3}{*}{$\begin{array}{c}\text { Aro. } \\
\text { MPI-1 }\end{array}$} \\
\hline & & & & & & & \\
\hline & & $" A " A " *$ & Sat. & Aro. & OEP & $\begin{array}{l}\text { LMW/ } \\
\text { HMW }\end{array}$ & \\
\hline \multicolumn{2}{|c|}{ Sample } & 19 & 2.2 & 1.4 & 2.89 & 0.54 & 0.13 \\
\hline \multirow{4}{*}{1} & 400 & 22.6 & 2.8 & 1.2 & 1.57 & 1.56 & 0.27 \\
\hline & 500 & 14.8 & 2.9 & 1.5 & 1.63 & 0.15 & 0.27 \\
\hline & 600 & 16.1 & 4.2 & 2.2 & 1.2 & 0.19 & 0.48 \\
\hline & 700 & 18.5 & 3.4 & 4.5 & 1.14 & 0.64 & 0.65 \\
\hline \multirow{4}{*}{3} & 400 & 18.5 & 2.9 & 2.4 & 1.95 & 0.14 & 0.38 \\
\hline & 500 & 22 & 3.9 & 3.9 & 2.03 & 0.11 & 0.65 \\
\hline & 600 & 24 & 5.9 & 3.7 & 1.46 & 0.62 & 0.68 \\
\hline & 700 & 11.5 & 2.3 & 4.6 & 1.17 & 2.22 & 0.88 \\
\hline
\end{tabular}

"A": content of chloroform bitumen "A"; Sat.: saturated hydrocarbons; Aro.: aromatic hydrocarbons; OEP = $\left(n C_{25}+6 n C_{27}+n C_{29}\right) /\left(4 n C_{26}+4 n C_{28}\right)$; LMW/HMW: Sum of $n C_{12}-n C_{21}$ alkane relative to sum of $n C_{22}-n C_{35}$ alkanes.

mesh and the powdered samples were extracted using a Soxhlet apparatus with chloroform for $48 \mathrm{hr}$. The extractable organic matter from the pyrolysates was deasphalted by precipitation with $n$-hexane followed by filtration. The extracts were fractionated by column chromatography on alumina over silica gel. Saturated hydrocarbons, aromatic hydrocarbons and nonhydrocarbons were obtained by successively eluting with $n$-hexane, toluene and chloroform/methanol (98:2), respectively. The saturated hydrocarbons were analyzed with an Agilent 6890N GC/5973N mass spectrometer (GC-MS). Helium was used as the carrier gas. Sample extracts were injected in splitless mode at $250^{\circ} \mathrm{C}$ into an $\mathrm{HP}-5$ column $(30 \mathrm{~m} \times 0.25$ $\mathrm{mm} \times 0.25 \mu \mathrm{m})$ at an initial temperature of $80^{\circ} \mathrm{C}$. The temperature was raised at $4{ }^{\circ} \mathrm{C} / \mathrm{min}$ to $290^{\circ} \mathrm{C}$ and held for $30 \mathrm{~min}$. The mass spectrometer was operated at an electron energy of $70 \mathrm{eV}$ with an ion source temperature of $250^{\circ} \mathrm{C}$ (Wang et al., 2006).

Tricyclic terpanes, $\mathrm{C}_{24}$ tetracyclic terpane and all hopanes were identified on the basis of mass fragmentographic responses and relative retention times compared with "standard" samples and the literature. Biomarker ratios and compound identification used peak areas from the $\mathrm{m} / \mathrm{z} 191$ chromatograms.

\section{RESULTS AND DISCUSSION}

Characteristics of group components

A dynamic equilibrium between the products (liquid hydrocarbons) and indissoluble organic matter was maintained under the experimental conditions. The content of chloroform bitumen " $\mathrm{A}$ " in the pyrolysates ranged from 11.5 to $22.6 \mathrm{mg} / \mathrm{g}$ TOC (Table 1). At $1 \mathrm{GPa}$, peak values were approached at $400{ }^{\circ} \mathrm{C}$; at
$3 \mathrm{GPa}$, however, they were approached at $600{ }^{\circ} \mathrm{C}$.

These results are quite different from the results of experiments conducted at low pressures. For example, the yield of liquid pyrolysate of Eocene coal at temperatures of $250-700{ }^{\circ} \mathrm{C}$ with an interval temperature of $50{ }^{\circ} \mathrm{C}$ reached a maximum at $350{ }^{\circ} \mathrm{C}$ and decreased by $0.3 \mathrm{mg} / \mathrm{g}$ TOC at $600{ }^{\circ} \mathrm{C}$, and the maximum pressure of liquid pyrolysate was less than $40 \mathrm{MPa}$ (Xia et al., 1993).

The yields of saturated and aromatic hydrocarbons increase with increasing temperature, with the exception of that of saturates at $700{ }^{\circ} \mathrm{C}$, indicating that high pressures are unfavourable for decomposing liquid hydrocarbons into gaseous products.

The alkane distributions in the pyrolysates differed from those in lignite (Fig. 2). Under HPT conditions, most alkanes in the pyrolysates showed bimodal distributions, except at $700{ }^{\circ} \mathrm{C}$ (Wang et al., 2006). At a given pressure, the alkane distribution of the pyrolysates shows an increased trend of right-hand peaks and a decrease in LMW/HMW (the ratio between low molecular weight and high molecular weight constituents) with increasing temperature between 400 and $500{ }^{\circ} \mathrm{C}$ (Table 1). This may have resulted from the thermal cracking of huminite and the decomposition of soluble organic matter (humic acids and asphaltene) which are more easily decomposed into short-chain alkanes at lower temperatures. However, the alkane distributions of the pyrolysates show an increased trend of left-hand peaks when temperatures were higher than $600{ }^{\circ} \mathrm{C}$, and an increase in $\mathrm{LMW} / \mathrm{HMW}$ values. At $700^{\circ} \mathrm{C}$, the alkane distributions become unimodal, and the carbon number of the main peak decreased. The variation of peak forms indicates that thermal decomposition of organic matter in the system became predominant, resulting 

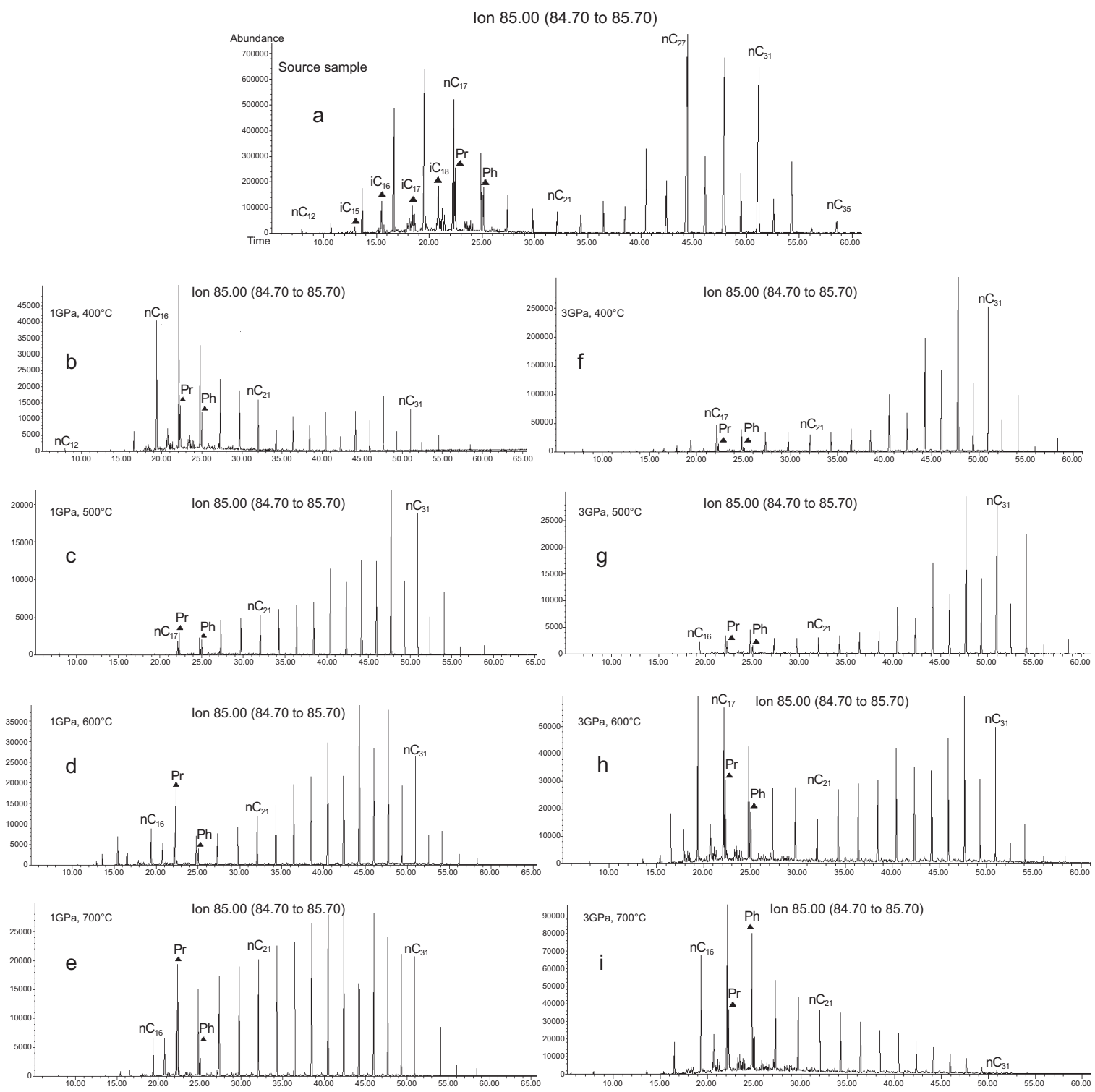

Fig. 2. GC-MS chromatograms of $n$-alkanes extracted from lignite sample (a) and from the high P-T pyrolysates (b-i), showing the distribution patterns of acyclic alkanes in samples produced under different high P-T conditions. The abscissa denotes retention time(s) and the ordinate relative intensity. Pr: pristane; Ph: phytane; $n \mathrm{Ci}$ and $\mathrm{iCi}$ : normal alkanes and iso- alkanes with carbon number $i$.

in demethylation and breakage of chains and rings within the organic material.

OEP values (Table 1) decrease with increasing temperatures at a given pressure as a result of thermal degradation. OEP values at $3 \mathrm{GPa}$ are generally higher than those at $1 \mathrm{GPa}$. Also, the methyl phenanthrene index (MPI-1) (Sivan et al., 2008) increases with increasing temperatures at a given pressure, and the MPI-1 at $3 \mathrm{GPa}$ is higher than that at $1 \mathrm{GPa}$ (Table 1).

These results show that the maturation of organic matter is increased with increasing temperatures at constant pressures, but that pressure retards the generation and maturation of hydrocarbons, especially at relatively low temperatures in the range of 400 to $500^{\circ} \mathrm{C}$, confirming the results of Wang et al. (2006, 2007). Consistent with previous studies, the results also suggest that the geological factors determining the hierarchies of overpressure retardation are very complex.

The effects of overpressure on different aspects of organic matter maturation were examined in three basins using multiple parameters by Hao et al. (2007). Their observations suggest differential retardation of organic matter maturation (that is, different organic matter maturation reactions and different maturity parameters have been retarded by overpressure to different degrees in the same overpressured system), with up to four hierarchies of overpressure retardation. Conflicting ideas about the function of pressure and/or overpressure in organic matter maturation and hydrocarbon generation may reflect the complexities of the effects of overpressure. 

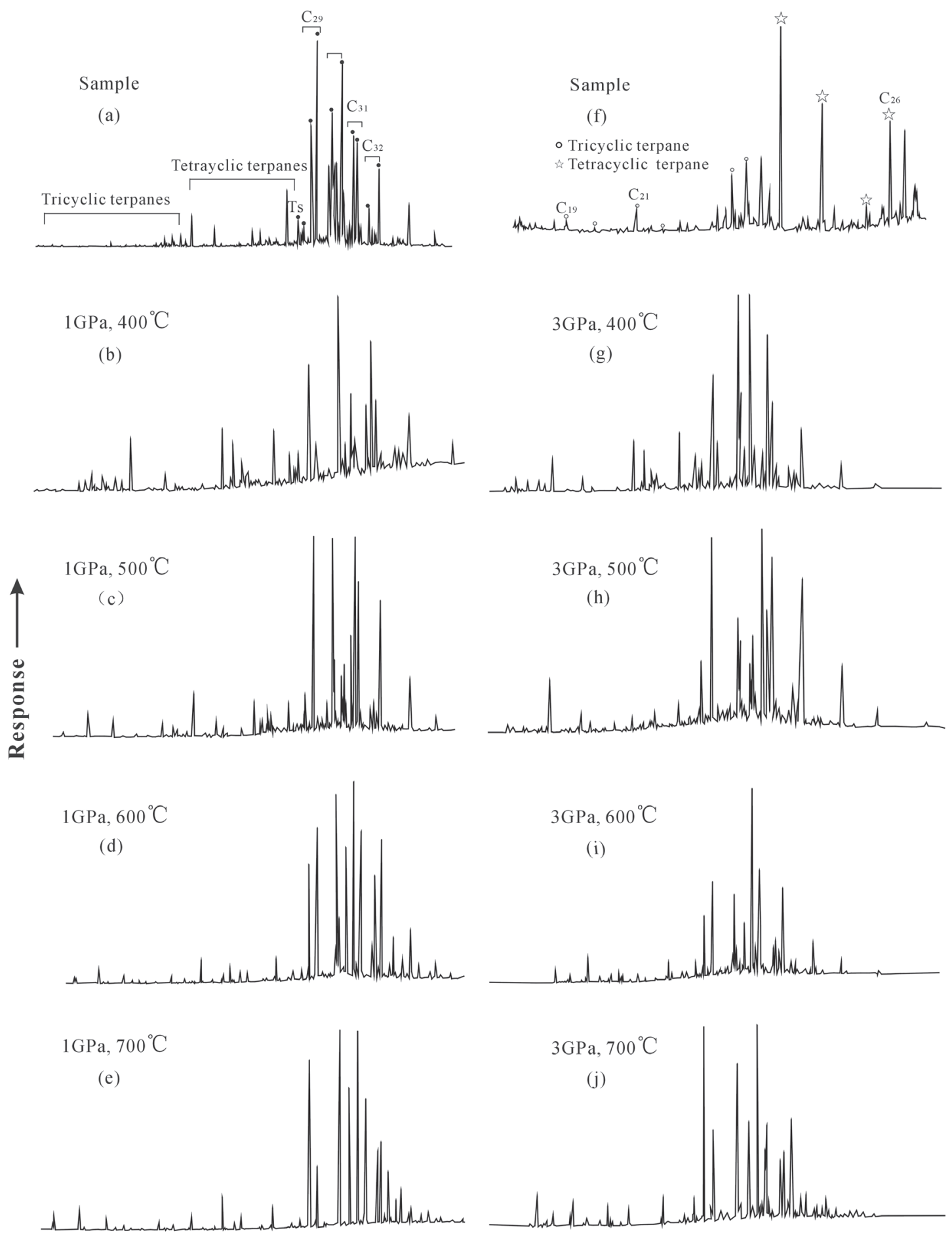

Retention time $\longrightarrow$

Fig. 3. GC-MS chromatograms of terpanes extracted from the initial lignite $(a, f)$, from experimental pyrolysates at I GPa (b,c,d,e), and from pyrolysates at $3 \mathrm{GPa}(\mathrm{g}, \mathrm{h}, \mathrm{i}, \mathrm{j})$, showing the distribution patterns and variations of abundances of individual terpanes under HPT conditions.

Distribution and isomerization of terpanes

(i) Tricyclic terpanes

Tricylic terpanes are found in most crude oils and source rocks, and occur as a pseudo-homologous series ranging from $\mathrm{C}_{19}$ to $\mathrm{C}_{54}$ (de Grande et al., 1993; Paul et al., 1999). However, tricylic terpanes are commonly only recognized up to the $\mathrm{C}_{29}$ compounds.
The $\mathrm{C}_{23}$ member is often the dominant homologue in crude oils derived from a marine source rock; while the $\mathrm{C}_{19}$ and $\mathrm{C}_{20}$ members are found to be more abundant in terrestrial-sourced oils (Peters and Moldowan, 1993). The lignite analysed in this study is derived from terrigenous organic matter deposited under a weakly oxic environment (Wang et al., 2006; 2007). 

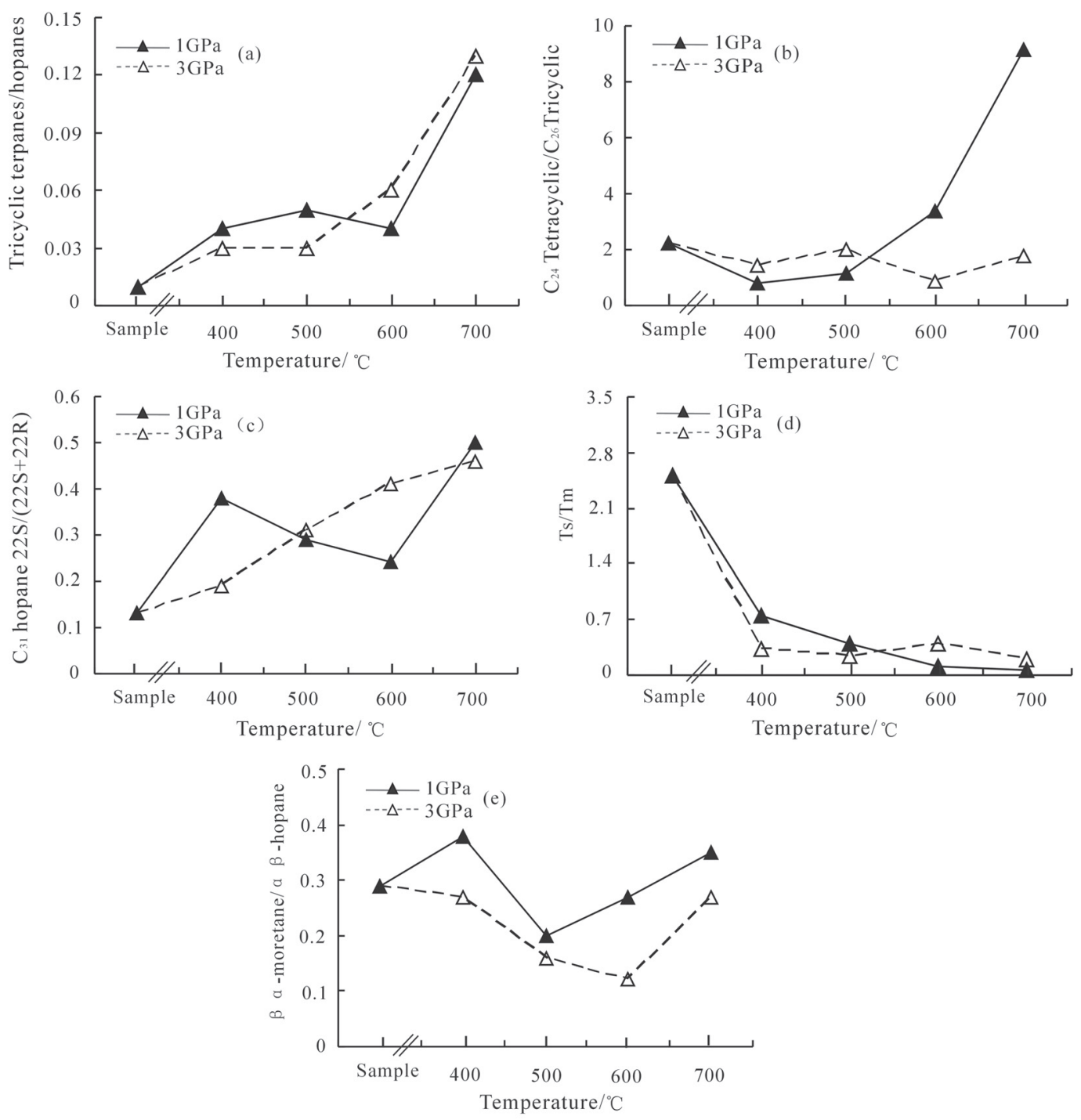

Fig. 4. Parameter ratios of terpanes from the initial lignite sample and from pyrolyzates produced under different pressure and temperature conditions. See text for details.

Tricyclic terpanes ranging from $\mathrm{C}_{19}$ to $\mathrm{C}_{26}$, with peaks at $\mathrm{C}_{24}$ and $\mathrm{C}_{20}$ for the lignite sample and the pyrolysate, were identified on the $\mathrm{m} / \mathrm{z}, 191$ mass spectra (Fig. 3).

The ratio of tricyclic terpanes to hopanes gently increases at 400, 500 and $600{ }^{\circ} \mathrm{C}$, and more strongly at $700{ }^{\circ} \mathrm{C}$ at pressures of 1 and $3 \mathrm{GPa}$ (Fig. 4a). This is due to the greater thermal stability of tricyclic terpanes relative to hopanes (Van Grass et al., 1981) and/or the greater relative generation of tricyclics from kerogen at high maturities (Peters and Moldowan, 1993). The tricyclic/hopanes ratio decreases with increasing pressure from 1 to $3 \mathrm{GPa}$ at $\sim 400-500{ }^{\circ} \mathrm{C}$ but increases at $\sim 600-700{ }^{\circ} \mathrm{C}$ (Fig. 4a). Therefore it seems that pressure appears to retard the thermal maturation of organic matter at lower temperatures, but favours the generation of tricyclics from kerogen at higher temperatures for heating times of $120 \mathrm{~min}$. This was also demonstrated by variations of $n$-alkane and aromatic parameters in pyrolyzates (Wang et al., 2006; 2007). (ii) Tetracyclic terpanes

$\mathrm{C}_{24}$ tetracyclic terpanes were detected in pyrolysates at comparable or slightly higher relative intensities compared to $\mathrm{C}_{26}$ tricyclic terpanes. The proportion of $\mathrm{C}_{24}$ tetracyclic terpanes relative to tricyclic terpanes may be facies dependent, and high amounts of $\mathrm{C}_{24}$ tetracyclic terpanes have been found in carbonates (e.g. Connan et al., 1986) and terrestrial samples (Philp and Fan, 1987).

The $\mathrm{C}_{24}$ tetracyclic terpane / $\mathrm{C}_{26}(\mathrm{~S}+\mathrm{R})$ tricyclic terpane ratio in the lignite samples was 2.25 , consistent with a derivation from terrigenous higher plant material (Fig. 4b). However, at $1 \mathrm{GPa}$, the ratio decreased to 0.81 at $400^{\circ} \mathrm{C}$ and then sharply increases to 9.15 at $700{ }^{\circ} \mathrm{C}$ (Fig. 4b). At $3 \mathrm{GPa}$, it slowly increased from 1.44 at $400{ }^{\circ} \mathrm{C}$ to 2.00 at $500{ }^{\circ} \mathrm{C}$, followed by a decrease to 0.84 at $600^{\circ} \mathrm{C}$, and then an increase to 1.80 at $700{ }^{\circ} \mathrm{C}$ (Fig. 4 b).

The $\mathrm{C}_{24}$ tetracyclic terpane / $\mathrm{C}_{26}(\mathrm{~S}+\mathrm{R})$ tricyclic terpane ratio decreases at $\sim 400-500{ }^{\circ} \mathrm{C}$ and then 
a

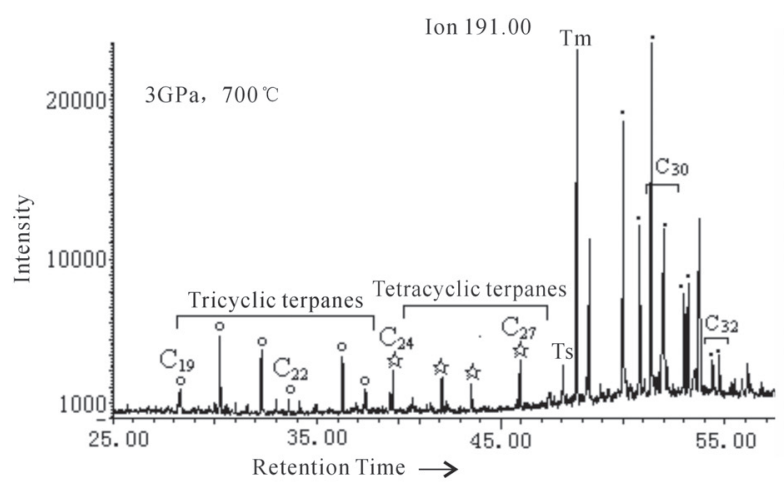

C

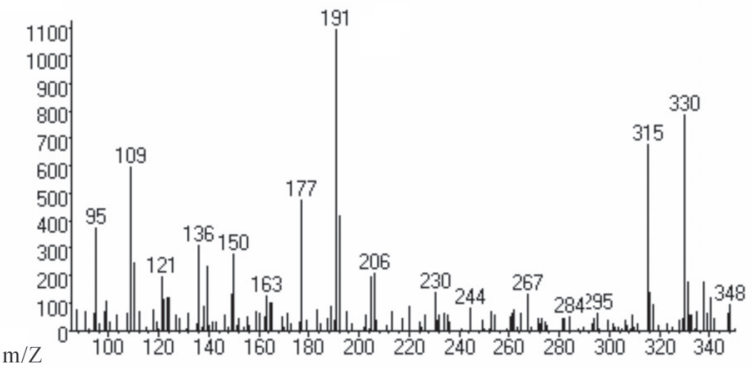

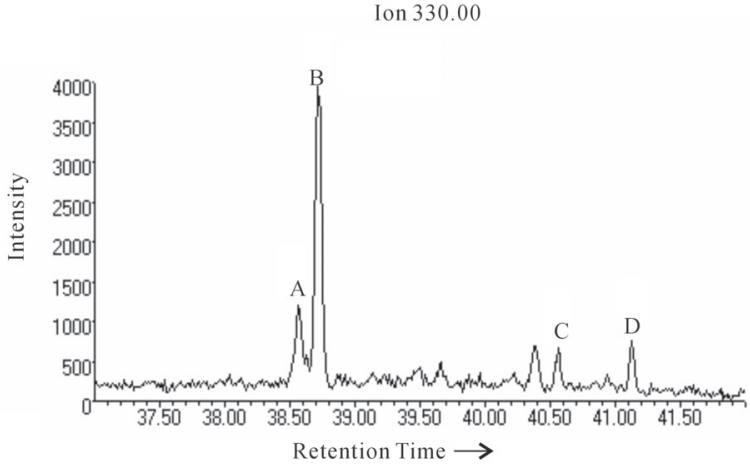

d

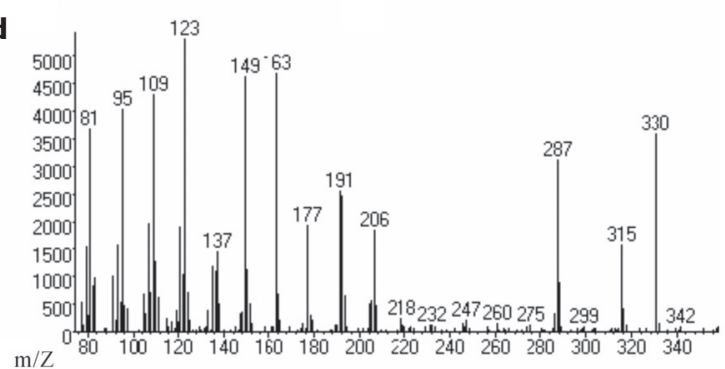

f

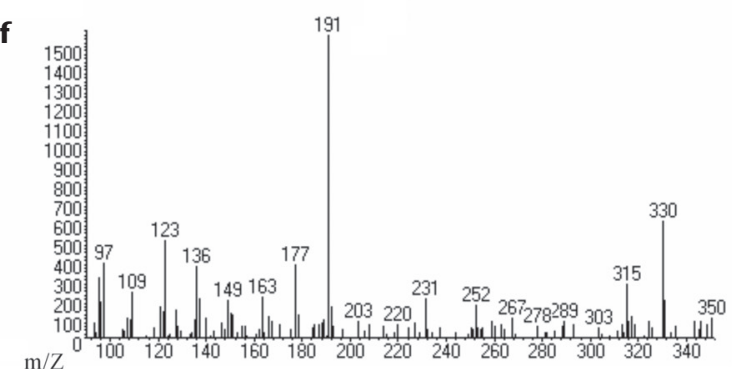

Fig. 5. a, b. TICs of tricyclic terpanes (m/z I9I) and tetracyclic terpanes ( $\mathrm{m} / \mathrm{z} 330)$; c-e. mass spectra of four $\mathrm{C}_{24}$ tetracyclic terpanes in the studied pyrolysate samples at $700^{\circ} \mathrm{C}$ and $3 \mathrm{GPa}$.

increases at $\sim 600-700{ }^{\circ} \mathrm{C}$ with increasing pressures. Therefore, it seems reasonable to conclude that this ratio is controlled by temperature and pressure, and not only by the sedimentary environment.

Of particular interest was the occurrence of several $\mathrm{C}_{24}$ tetracyclic terpanes in the studied samples. In addition to the ubiquitous tetracyclic 17,21-secohopane (peak D in Fig. 5b), the pyrolysate also contained $10 \beta(\mathrm{H})$-des-A-oleanane, $10 \beta(\mathrm{H})$-des-A-lupane and $10 \beta(\mathrm{H})$-des-A-ursane (peaks: A, B, and C in Fig. 5b, respectively). To analyze these various compounds, mass spectra have both an $\mathrm{m} / \mathrm{z} 191$ base peak, a molecular ion at $m / z 330$ and an important $\mathrm{M}+(-15)$ at $\mathrm{m} / \mathrm{z} 315$. The isomers of tetracyclic terpane including $10 \beta(\mathrm{H})$-des-A-lupane, $10 \beta(\mathrm{H})$-des-A-ursane, $\mathrm{C}_{24}$-17,21secohopane and $10 \beta(\mathrm{H})$-des-A-oleanane show a decreasing relative abundance in the studied samples at $700^{\circ} \mathrm{C}$ and $3 \mathrm{GPa}$ (Fig. 5b). These triterpanes are derived from degradation processes acting on various triterpenoid precursors present in higher plants during early diagenesis (Aquino et al., 1982). Woolhouse et al. (1992) found these triterpanes in terrestrially sourced oils. The presence of these compounds in the present study is thus consistent with the sources of lignite from terrigenous higher plant material (Wang et al., 2006).

\section{(iii) Pentacyclic terpanes}

Pentacyclic terpanes record information concerning organic matter type, maturity level, source-rock lithology, and migration of hydrocarbons (Seifert et al, 1980; Blanc and Connan, 1992). The $18 \alpha(\mathrm{H})-$ 22,29,30-trisnorhopane (Ts) and $17 \alpha(\mathrm{H})-22,29,30$ trisnorhopane $(\mathrm{Tm})$, two $\mathrm{C}_{27}$ pentacyclic tristerpanes, are often analysed to assess the maturity level of a source rock (Rullkotter and Marzi, 1988; Peters and Moldowan, 1993). Tm shows relatively lower stability than Ts during maturation (Arfaoui et al., 2007).

At $1 \mathrm{GPa}$, the Ts/Tm ratio decreased sharply from 0.75 to 0.08 with increasing temperatures from $400{ }^{\circ} \mathrm{C}$ to $700{ }^{\circ} \mathrm{C}$ (Fig. $4 \mathrm{~d}$ ); and at $3 \mathrm{GPa}$, the $\mathrm{Ts} / \mathrm{Tm}$ ratio also decreased from 0.33 at $400{ }^{\circ} \mathrm{C}$ to 0.19 at $700{ }^{\circ} \mathrm{C}$ (Fig. 4d). Therefore, Tm in the 
Table 2. Terpane parameters of the studied samples.

$C_{\text {Max }}$ : peak of tricyclics; tri/hop: the sum of $C_{19}-C_{26}$ tricyclics / $C_{27}-C_{34}$ hopanes; $C_{24}$ TeT / $C_{26}$ TT: $C_{24}$ tetracyclic terpanes $/ C_{26}(S+R)$ tricyclic terpanes; $\beta \alpha / \alpha \beta$ : the ratio of $I 7 \beta(H), 2 I \alpha(H)$-Moretane $/ C_{30} I 7 \alpha(H), 2 I \beta(H)-$ hopane; $C_{31} S^{26} C_{31}$ hopane $22 S /(22 S+22 R)$.

\begin{tabular}{|c|c|c|c|c|c|c|c|}
\hline \multirow{2}{*}{$\begin{array}{c}\mathbf{P} \\
\text { (GPa) }\end{array}$} & \multirow{2}{*}{$\mathbf{T}\left({ }^{\circ} \mathrm{C}\right)$} & \multicolumn{2}{|c|}{ Tricyclics } & Tetracyclics & \multicolumn{3}{|c|}{ Pentacyclics } \\
\cline { 3 - 8 } & & $\mathbf{C}_{\mathbf{M a x}}$ & $\mathbf{t r i} / \mathbf{h o p}$ & $\mathbf{C}_{\mathbf{2 4}} \mathbf{T e T} / \mathbf{C}_{\mathbf{2 6}} \mathbf{T T}$ & $\mathbf{T s} / \mathbf{T m}$ & $\boldsymbol{\beta \alpha} / \boldsymbol{\alpha} \boldsymbol{\beta}$ & $\mathbf{C}_{\mathbf{3 1}} \mathbf{S}$ \\
\hline \multicolumn{2}{|c|}{ Sample } & $\mathrm{C}_{24}$ & 0.01 & 2.25 & 2.5 & 0.29 & 0.13 \\
\hline \multirow{4}{*}{1} & 400 & $\mathrm{C}_{20}$ & 0.04 & 0.81 & 0.75 & 0.38 & 0.38 \\
\cline { 2 - 9 } & 500 & $\mathrm{C}_{20}$ & 0.05 & 1.14 & 0.4 & 0.2 & 0.29 \\
\cline { 2 - 9 } & 600 & $\mathrm{C}_{20}$ & 0.04 & 3.35 & 0.1 & 0.27 & 0.24 \\
\cline { 2 - 9 } & 700 & $\mathrm{C}_{20}$ & 0.12 & 9.15 & 0.08 & 0.35 & 0.5 \\
\hline \multirow{4}{*}{3} & 400 & $\mathrm{C}_{24}$ & 0.03 & 1.44 & 0.33 & 0.27 & 0.19 \\
\cline { 2 - 9 } & 500 & $\mathrm{C}_{21}$ & 0.03 & 2 & 0.25 & 0.16 & 0.31 \\
\cline { 2 - 9 } & 600 & $\mathrm{C}_{20}$ & 0.06 & 0.84 & 0.4 & 0.12 & 0.41 \\
\cline { 2 - 9 } & 700 & $\mathrm{C}_{20}$ & 0.13 & 1.8 & 0.19 & 0.27 & 0.46 \\
\hline
\end{tabular}

pyrolysate can be attributed to the source rather than the maturity, as indicated by the $\mathrm{Ts} / \mathrm{Tm}$ ratio data (Table 2). The $\mathrm{Ts} / \mathrm{Tm}$ ratio decreased at lower temperatures $\left(\sim 400-500{ }^{\circ} \mathrm{C}\right)$ and then increased at higher temperatures $\left(\sim 600-700{ }^{\circ} \mathrm{C}\right)$ with increasing pressures (Fig. 4d). The results suggest that pressure can retard the transformation of biological isomers into geochemical isomers at relatively low temperatures, but probably favours the transformation at higher temperatures. This result is consistent with the inference that overpressure retardation of organic matter maturation only takes place under certain conditions (Li et al., 2004).

Isomerization ratios of $22 \mathrm{~S} /(22 \mathrm{~S}+22 \mathrm{R})$ for homohopanes are the most frequently used hopanebased thermal maturity parameters (e.g. Seifert and Moldowan, 1980; Peters and Moldowan, 1993; Lockhart et al., 2008; Duan et al., 2008). As the biologically produced $22 \mathrm{R}$ homohopanes can gradually be transformed into a mixture of $22 \mathrm{R}$ and $22 \mathrm{~S} \alpha \beta$-diastereomers, the $22 \mathrm{~S} /(22 \mathrm{~S}+22 \mathrm{R})$ ratio of $\mathrm{C}_{31} \alpha \beta$ - homohopanes or other homologues $\left(\mathrm{C}_{32}\right.$, etc. $)$ can be used as a thermal maturity parameter. The $22 \mathrm{~S} /(22 \mathrm{~S}+22 \mathrm{R})$ ratio increases from 0 to about 0.6 $(0.57-0.62=$ equilibrium $)$ during maturation (Seifert and Moldowan, 1978). Fig. 4c shows that the 22S/ $(22 \mathrm{~S}+22 \mathrm{R})$ ratio of the $\mathrm{C}_{31}$ hopanes in the source (lignite) sample is 0.13 , then rises to 0.50 at $700{ }^{\circ} \mathrm{C}$ at $1 \mathrm{GPa}$. At $3 \mathrm{GPa}$, the ratio increases with increasing maturity from 0.19 at $400{ }^{\circ} \mathrm{C}$ to 0.46 at $700{ }^{\circ} \mathrm{C}$. Thus at a given temperature, the $22 \mathrm{~S} /(22 \mathrm{~S}+22 \mathrm{R})$ ratio of $\mathrm{C}_{31}$ hopanes shows no clear trend with increasing pressure. Based on these results, however, it can be inferred that the $22 \mathrm{~S} /(22 \mathrm{~S}+22 \mathrm{R})$ homohopane epimer ratio may be controlled by other factors besides thermal "isomerization", such as depositional environment. Furthermore, the epimer ratios at given experimental temperatures vary for different types of rock.

Reversals in the trends of the epimer ratios also occur in natural samples. For example, Curiale and Odermatt (1989) observed a reduction in the 22S/ (22S+22R) ratio with depth in Monterey Formation samples from the Santa Maria Basin. Also high pressures may affect the pyrolysis of organic matter in a non-linear fashion, resulting in anomalous variations of the maturation parameters.

The values of the $\mathrm{C}_{31}$ hopane $22 \mathrm{~S} /(22 \mathrm{~S}+22 \mathrm{R})$ ratio in our samples range from 0.46 to 0.50 at $700{ }^{\circ} \mathrm{C}$, which implies that isomerizations at the $\mathrm{C}-22$ position in the hopane have not attained the typical transfer equilibrium because of the high pressures and/or the short heating duration.

The ratio of $17 \beta(\mathrm{H}), 21 \alpha(\mathrm{H})$-moretanes over the corresponding $17 \alpha(\mathrm{H}), 21 \beta(\mathrm{H})$-hopane (i.e. $\beta \alpha$ moretane/ $\alpha \beta$-hopane) decreases with increasing thermal maturity. This parameter decreases from about 0.8 at immaturity to less than 0.15 with maturity and to a minimum of 0.05 (Rullkotter and Marzi, 1988; Peters and Moldowan, 1993). Values of the $\beta \alpha-$ moretane/ $\alpha \beta$-hopane ratio for the samples analysed are listed in Table 2 (see also Fig. 4e). Values of the ratio for the lignite sample and for pyrolysates are 0.29 and $0.12 \sim 0.38$, respectively. This indicates that the samples are in the early stages of maturity. At 1 $\mathrm{GPa}$, the ratio decreased from 0.38 to 0.15 with increasing temperature from $400{ }^{\circ} \mathrm{C}$ to $600^{\circ} \mathrm{C}$, then increased to 0.35 at $700{ }^{\circ} \mathrm{C}$. At $3 \mathrm{GPa}$, the ratio followed a similar trend, with a significant decrease from 0.27 at $400{ }^{\circ} \mathrm{C}$ to 0.12 at $600{ }^{\circ} \mathrm{C}$, followed by an increase to 0.27 at $700{ }^{\circ} \mathrm{C}$. The fact that the ratio increased at $700^{\circ} \mathrm{C}$ indicates an increase of $17 \beta(\mathrm{H}), 21 \alpha(\mathrm{H})$-moretanes, which points to the reduced thermal degradation of kerogen. At a given 
temperature, the ratio shows an apparent decreasing trend with increasing pressure from $1 \mathrm{GPa}$ to $3 \mathrm{GPa}$ (Fig. 4e).

These results suggest that under constant pressure, and for a heating time of $120 \mathrm{~min}$, the maturation of organic matter was enhanced with increasing temperature; but that pressure retarded the generation and maturation of hydrocarbons, especially at lower temperatures, as also demonstrated by other parameters involving saturated and aromatic hydrocarbons (Wang et al., 2006; 2007).

\section{Temperature and pressure effects on the thermal evolution of organic matter}

Temperature and pressure have inter-related effects on the maturation of organic matter and hydrocarbon generation. Because the rate of chemical processes involved in organic matter maturation are governed by the first-order Arrhenius equation, geological time should be compensated for by higher temperatures than those occurring in natural environments. The Arrhenius equation gives the dependence of the rate constant $(\mathrm{k})$ of a chemical reaction on the temperature $\left(\mathrm{T},{ }^{\circ} \mathrm{K}\right)$ and activation energy, $\mathrm{E}_{\mathrm{a}}$, as follows:

$$
\mathrm{k}=\mathrm{Ae}^{-\mathrm{Ea} / \mathrm{RT}}
$$

where $\mathrm{A}$ is the pre-exponential factor and $\mathrm{R}$ is the universal gas constant.

It is generally accepted that temperature and time are critical factors in the generation of hydrocarbons in accordance with the principles of chemical kinetics (e.g. Hunt, 1996; Zou and Peng, 2001). This is because an increase in temperature enables the reacting molecule to achieve a transition state, thereby exceeding the Ea value and forming a product molecule. Increasing temperatures favour the transformation of immature organic matter into oil, at the same time inducing an increase in pressure in a confined pyrolysis system. Consequently, the collision probability ("A" in the Arrhenius equation) among hydrocarbon molecules is enhanced in a high pressure system. However, more thermal energy must be consumed in order to overcome pressure, resulting in the retarded maturation of organic compounds at a given burial depth, and reducing the total yield of gas and enhancing the yield of liquid oils. Increasing pressure increases the activation energy; thermal energy must be transferred from the kerogen into the incompressible water to allow the kerogen to expand into its activated state. The higher the pressure, the more energy is transferred from the kerogen in this way and the reaction is retarded (Uguna et al., 2012).

Theoretical considerations and the experimental results presented in this study and in Carr et al. (2009) indicate that both temperature and pressure exert significant controls on the extent of endothermic reactions, such as hydrocarbon generation and maturation reactions. Increasing temperature produces an increase in total hydrocarbon yield and maturation, whereas increases in pressure have the opposite effect, that is, hydrocarbon generation yields and maturation values are lower as reaction rates are retarded (Uguna et al., 2012).

In transition state theory, reaction rates are controlled by the activation volume, which is the volume difference between the activated complex and reactant. If the activation volume is negative, then the reaction rate constant increases with increasing pressure. Conversely, if volume increases when the activated complex is formed, then pressure should slow the reaction rates.

Considerable amounts of liquid hydrocarbons with carbon numbers up to $\mathrm{C}_{35}$ and isoprenoid hydrocarbons with relatively low thermal stability were found at $3 \mathrm{GPa}$ and $700{ }^{\circ} \mathrm{C}$ (Wang et al., 2006); this pressure-temperature condition exceeds the P-T conditions in sedimentary basins where liquid hydrocarbons are commonly found. Isomerizations at the $\mathrm{C}-22$ position in hopane did not attain the rearrangement equilibrium, even at $700{ }^{\circ} \mathrm{C}$. Under constant pressures, the maturation of organic matter is enhanced with increasing temperature, but the thermal evolution of organic matter is significantly hindered by high pressure.

"Reversals" in the trends of some epimer ratios with increasing pressure have been found in natural samples, indicating that the influence of overpressure on organic matter maturation is non-linear. For example, Hao et al. (2007) observed that the overall influence of overpressure on organic matter maturation may differ in different basins (e.g. the Yinggehai and Qingdongnan Basins and Dongpu Depression). At early stages of organic matter maturation, the thermal degradation of kerogen contributes to large volume expansion effects (Wang et al., 2007). As a result, early-developed overpressures may retard the thermal degradation of kerogens (Hao et al., 2007). However, most degradable fractions in kerogen structures are lost at late stages of organic matter maturation (after peak oil generation), and the further maturation of kerogens will have lower product yields and lesser volume expansion effects. By contrast, the cracking of liquid hydrocarbons can enhance the effects of volume expansion (Hao et al., 2007). As a result, late-developed overpressures may not retard kerogen degradation and maturity parameters during kerogen thermal evolution, such as Ts/Tm, $\mathrm{C}_{31} 22 \mathrm{~S} /(22 \mathrm{~S}+22 \mathrm{R})$ and $\beta \alpha$-moretane / $\alpha \beta$-hopane. However, they may retard the thermal cracking of liquid hydrocarbons significantly (Wang et al., 2006). Also, water can play an important role in the evolution of organic matter 
and in hydrocarbon generation by exchange reactions of hydrogen and oxygen with organic matter (Landais et al., 1994). Supercritical water $\left(\mathrm{Tc}=374^{\circ} \mathrm{C}, \mathrm{Pc}=\right.$ $22.1 \mathrm{MPa}$ ) with strong dissolubility (Frank and Foster, 2000; Tian et al., 2002) can reduce reaction temperatures, and thus speed up pyrolysis reactions involving organic compounds.

\section{CONCLUSIONS}

Considering the widespread occurrence of terpanes and their persistence at high maturity levels, understanding their distribution under HPT conditions is important. Both high temperatures and high pressures play important roles in influencing chemical reactions undergone by organic matter during HPT pyrolysis. The results from HPT pyrolysis of lignite with water in a closed system under extreme conditions are significantly different from those indicated by previous experiments at low pressures. The results confirm that organic matter maturity increases with increasing temperature at a given pressure; and that increasing pressure significantly controls all aspects of organic matter metamorphism, including hydrocarbon generation, maturation and thermal destruction, especially at lower temperatures. Moreover, high pressure affects the maturity of organic matter non-linearly, resulting in anomalous variations of maturation parameters involving terpanes (tricyclic/hopanes, Ts/Tm, $\mathrm{C}_{31} 22 \mathrm{~S} /(22 \mathrm{~S}+22 \mathrm{R}), \beta \alpha-$ moretane / $\alpha \beta$-hopane). In addition, the values of the $\mathrm{C}_{31}$ hopane $22 \mathrm{~S} /(22 \mathrm{~S}+22 \mathrm{R})$ ratio range from 0.46 to 0.50 at $700{ }^{\circ} \mathrm{C}$, which implies that isomerizations at the $\mathrm{C}-22$ position in the hopane has not attained the re-arrangement equilibrium. The HPT experimental data demonstrate that high pressure strongly suppresses the maturation of organic matter for a heating duration of $120 \mathrm{~min}$ and contributes to preserving the terpanes signatures in the molecular biomarkers.

\section{ACKNOWLEDGEMENTS}

The authors are grateful to Senior Engineers Qianxiang Meng and Wanren Ding for their help with GC-MS analyses and interpretation of mass spectra. They acknowledge JPG editorial staff for help with the English language presentation. Reviews by A. C. Carr (Advanced Geochemical Systems Ltd), Ronan Le Bayon (Technische Universität Darmstadt) and an anonymous referee are acknowledged with thanks and improved the quality of the manuscript. This study was supported by the National Natural Science Foundation of China (Grant Nos. 40806048; 40873049) and Key Projects in the Yantai Science \& Technology Pillar Program (2011060).

\section{REFERENCES}

ARFAOUI, A., MONTACER, M., KAMOUN, F., and RIGANE, A., 2007. Comparative study between Rock-Eval pyrolysis and biomarkers parameters: A case study of Ypresian source rocks in central-northern Tunisia. Marine and Petroleum Geology, 24, 566-578.

BLAC, P.H., and CONNAN, J., 1992. Origin and occurrence of 25-nor-hopanes: a statistical study. Org. Geochem., I8, 813-828.

BRAUN, A.L., and BURHAM, A.K., 1990. Mathematical model of oil generation, degradation, and expulsion. Energy and Fuel, 4, I32-I46.

CARR, A.D., 1999. A vitrinite reflectance kinetic model incorporation overpressure retardation. Marine Petroleum Geology, 16, 355-377.

CARR, A.D., UGUAN, C., SNAPE, C.E., MEREDITH, W., SCOTCHMAN, I.C., and DAVIS, R.C., 2009. Retardation by Water Pressure of Hydrocarbon Generation Reactions in Geological Basins: An Experimental Investigation. Abstracts, AAPG Hedberg Research Conference, California, May, 2009.

CONNAN, J., BOUROULLEC, J., DESSORT, D., and ALBRECHT, P., 1986. Microbial input in carbonateanhydrite facies of a sabkha palaeoenvironment from Guatemala: a molecular approach. Org. Geochem, 10, 2950.

CURIALE, J.A., and ODERMATT, J.R., I989. Short-term biomarker variability in the Monterey Formation, Santa Maria Basin. Org. Geochem., I4, I-I3.

DE GRANDE, S.M.B.,AQUINO NETO, F.R., and MELLO, M.R., 1993. Extended tricyclic terpanes in sediments and petroleums. Org. Geochem., 20, 1039-1047.

DEINES, P., 2002.The carbon isotope geochemistry of mantle xenoliths. Earth-Science Reviews, 58, 247-278.

DU, J.G., JIN, Z.J, XIE, H.S., BAI, L.P. and LIU,W., 2003. Stable carbon isotope compositions of gaseous hydrocarbons produced from high pressure and high temperature pyrolysis of lignite. Org. Geochem., 34, 97-104

DUAN,Y.,WANG, C.Y., ZHENG, C.Y.,WU, B.X., and ZHENG, G.D., 2008. Geochemical study of crude oils from Xifeng oilfield of Ordos basin, China. Journ. SE Asian Earth Sciences, 3I, 34I-356.

FRANK, P.L. and FOSTER, N.R., 2000. Solubilities of solid mixtures in supercritical carbon dioxide: a review. The Journal of Supercritical Fluids, I 7, I I I-134.

HAO, F., SUN, Y., LI, S., and ZHANG, Q., 1995. Overpressure retardation of organic-matter maturation and petroleum generation: case study from the Yinggehai and Qiongdongnan Basins, S. China Sea. AAPG Bull., 79, 55I-562.

HAO, F., JIANG, J.Q., ZOU, H.Y., FANG, Y. and ZENG, Z.P., 2004. Differential retardation of organic matter maturation by overpressure. Sci. China Ser. D - Earth Sci. (in Chinese) 47, 783-793.

HAO, F., ZOU, H., GONG, Z., YANG, S., and ZENG, Z., 2007. Hierachies of overpressure retardation of organic matter maturation: Case studies from petroleum basins in China. AAPG Bull. 91, I467-|498.

HUNT, J.M., 1990. Generation and migration of petroleum from abnormally pressured fluid compartments. AAPG Bull., 74, $1-12$.

HUNT, J.M., 1996. Petroleum Geochemistry and Geology, 2nd Edition.W.H. Freeman New York

LANDAIS, P., MICHELS, R., and FLIE, M., 1994. Are time and temperature the only constraints to the simulation of organic matter maturity? Org. Geochem., 22, 617-630.

LE BAYON, R., BREY, G.P., ERNST, W.G., and FERREIRO MÄHLMANN, R., 20II. Experimental kinetic study of organic matter maturation: Time and pressure effects on vitrinite reflectance at $400{ }^{\circ} \mathrm{C}$. Organic Geochemistry, 42 , 
340-355.

LI, H.J., WU, T.R., MA, Z.J., and ZHANG,W.C., 2004. Pressure retardation of organic maturation in clastic reservoirs: a case study from the Banqiao Sag, Eastern China. Marine and Petroleum Geology, 2 I, I083-1093.

LOCKHART, R.S., MEREDITH, W., LOVE, G.D., and SNAPE C.E., 2008. Release of bound aliphatic biomarkers via hydropyrolysis from Type II kerogen at high maturity. Org. Geochem., 39, II I9-1 I 24.

McTAVISH, R.A., 1998. The role of overpressure in the retardation of organic matter maturation. Journ. Petrol. Geol. 2I, I53-186.

MONTHIOUX, M., LANDAIS, P., and DURAND, B., 1986. Comparison between extracts from natural and artificial maturation series of Mahakam delta coals. Org. Geochem., I0, 299-3| I.

OSBORNE, M.J., and SWARBRICK, R.E., 1997. Mechanisms for generating overpressure in sedimentary basins: $A$ reevaluation. AAPG Bull., 8 I, I023-104I.

PAUL, F., BEVAN, J.C., and BISHOP, A.N., 1999. Tricyclic terpane maturity parameters: response to heating by an igneous intrusion. Org. Geochem., 30, I011-1019.

PERSON, M. and GARVEN, G., 1992. Hydrologic constraints on petroleum generation within continental rift basins: Theory, and application to the Rhine graben. AAPG Bull. 76, 468-488.

PETERS, R.P. and GILBERT,T.D., 1986. Biomarker distributions in Australian oils predominantly derived from terrigenous source material. Org. Geochem., 2 I, 9I-105.

PETERS, K.E. and MOLDOWAN, J.M. (Eds.), 1993. The Biomarker Guide. interpreting molecular fossils in petroleum and ancient sediments. Pretice-Hall, NJ.

PHILP, R.P. and FAN, Z., 1987. Geochemical investigation of oils and source rocks from Qianjing Depression of Jianhan Basin, a terrigenous saline basin, China. Org. Geochem., I I, 549-562.

PRICE, L.C. and WENGER, L.M., 1992. Influence of pressure on petroleum generation and maturation as suggested by aqueous pyrolysis. Org. Geochem. 19, I4I-159.

RULLKOTTER, J. and MARZI, R., I988. Natural and artificial maturation of biological markers in a Toarcian shale from northern Germany. Org. Geochem., I3, 639-645.

SEIFERT,W.K. and MOLDOWAN, J.M., 1978. Applications of steranes, terpanes, and monoaromatics to the maturation, migration and source of crude oils. Geochimica et Cosmochimica Acta, 42, 77-95.
SEIFERT, W.K., MOLDOWAN, J.M., and JONES, R.W., 1980. Application of biological marker chemistry to petroleum exploration. Proceedings 10th WPC, I, 3 I4-327.

SEPHTON, M.A., WRIGHT, I.P., GILMOUR, I., DE LEEUW, J.W., GRADY, M.M., PHLIINGER, and C.T., 2002. High molecular weight organic matter in martian meteorites. Planetary and Space Science, 50, 7II-7I6.

SIVAN, P., DATTA, G.C., and SINGH, R.R., 2008. Aromatic biomarkers as indicators of source, depositional environment, maturity and secondary migration in the oils of Cambay Basin, India. Org. Geochem., 39, 1620-1630.

TIAN,Y.L., FENG, J.J., QIN,Y., CHEN, L., FANG, J.G., 2002, The Properties of Supercritical Water and Its Application in Chemical Reaction. Chemistry, 6, 396-402.

UGANA, C.N., C.E. SNAPE, W. MEREDITH, A.D. CARR, I.C. SCOTCHMAN, and R.C. DAVIS, 20I2, Retardation of hydrocarbon generation and maturation by water pressure in geologic basins:An experimental investigation, In: K. E. Peters, D. J. Curry and M. Kacewicz, (Eds), Basin Modeling: New Horizons in Research and Applications: AAPG Hedberg Series, 4, 19-37.

VAN GRASS, G., DE LEEUW, J., W., SCHENCK, P.A., and HAVERKAMP, J., 1981. Kerogen of Toarcian shales of the Paris Basin. A study of its maturation by flash pyrolysis techniques. Geochim. et Cosmochim. Acta, 45, 2465-2474.

WANG, C.Y., DU, J.G, WANG, W.C., XIE, H.S., CHEN, G.J., DUAN, Y., and ZHOU, X.C., 2006. Experimental study to confirm the existence of hydrocarbon under high pressure and temperature of deep lithosphere. Chinese Science Bulletin, 5 I, 1633-1638.

WANG, C.Y., DU, J.G, DUAN,Y.,WU, B.X., ZHENG, Z.Y., and ZHOU, X.C., 2007. Evolutive character of aromatics under high pressure and temperature of deep lithosphere. Science in China Series D-Earth Sciences, 50, 1488-1493.

WOOLHOUSE, A.D., QUNG, J.N., PHILP, R.P., and WESTON, R.J., 1992. Triterpanes and ring-A degraded triterpanes as biomarkers characteristic of Tertiary oils derived from predominantly higher plant sources. Org. Geochem., I8, 23-3I.

XIA,Y.Q., 1993. Study on pyrolysis of the Tertiary xyloid lignite from Nanning Basin. Dissertation for the Doctoral Degree. Lanzhou: Lanzhou Institute of Geology, Chinese Academy of Sciences. 3-5.

ZOU, Y.R., and PENG, P.A., 200I. Overpressure retardation of organic-matter maturation: a kinetics model and its application. Marine Petroleum Geology, I 8, 707-723. 